\title{
Food allergy: recent advances in pathophysiology and treatment
}

\author{
Julie Wang*, Hugh A Sampson
}

Division of Allergy and Immunology, Department of Pediatrics Mount Sinai Hospital, New York, NY, USA

\begin{abstract}
This is an Open Access article distributed under the terms of the Creative Commons Attribution Non-Commercial License (http://creativecommons.org/licenses/by-nc/3.0/) which permits unrestricted non-commercial use, distribution, and reproduction in any medium, provided the original work is properly cited.

Food allergies are adverse immune reactions to food proteins that affect up to $6 \%$ of children and 3-4\% of adults. A wide range of symptoms can occur depending on whether $\lg E$ or non-lgE mediated mechanism are involved. Many factors influence the development of oral tolerance, including route of exposure, genetics, age of the host, and allergen factors. Advances have been made in the understanding of how these factors interact in the pathophysiology of food allergy. Currently, the mainstay of treatment for food allergies is avoidance and ready access to emergency medications. However, with the improved understanding of tolerance and advances in characterization of food allergens, several therapeutic strategies have been developed and are currently being investigated as potential treatments and/or cures for food allergy.
\end{abstract}

Key Words: food hypersensitivity; allergy; anaphylaxis; oral tolerance; immunotherapy

\section{INTRODUCTION}

Food allergies are adverse immune reactions to food proteins that can range from immediate, potentially life-threatening reactions to chronic disorders such as atopic dermatitis and allergic gastrointestinal disorders. While many studies have investigated the prevalence of food allergies, few population studies have used the gold standard double-blind, placebo-controlled food challenges (DBPCFC) to confirm the diagnosis of food allergy, which can lead to an overestimated prevalence. A metaanalysis focusing on milk, egg, peanut, and seafood allergy found the prevalence of food allergies to be approximately $3.5 \%{ }^{1}$ The majority of the studies included in this meta-analysis used self-reports of food allergy, many utilized skin prick testing and food-specific IgE levels to confirm sensitization to the food allergens, and fewer employed DBPCFCs. The prevalence of food allergies has also been documented to have increased in the last 10-15 yrs, particularly in developed countries. Specifically, studies on peanut allergy in the US and UK indicate that the number of children affected has doubled, with the prevalence now over $1 \%$. ${ }^{2,3}$

The most common food allergens causing reactions in children include milk, egg, wheat, soy, peanuts, tree nuts, fish and shellfish. While the majority of children outgrow their allergy to milk, egg, wheat and soy, allergies to peanut, tree nuts, fish and shellfish often persist into adulthood. The persistence of food allergy is variable, depending on the specific food allergen. Re- cent reports indicate that it is taking longer for children to outgrow their milk and egg allergy, with most developing tolerance in their teenage years rather that in early school-age as previously thought. ${ }^{4,5}$ In contrast, only $20 \%$ of children with peanut allergy and 9\% with tree nut allergy will develop tolerance. ${ }^{6,7}$

The key to management of food allergies consists of education about food allergen avoidance and the use of emergency medications (e.g., epinephrine) for the treatment of allergic reactions. Although this approach is generally effective, avoidance can be very difficult since many common food allergens are ubiquitous in the diet. ${ }^{8}$ Therefore, patients and their families often experience a significant negative impact on their quality of life. ${ }^{9}$ Furthermore, food allergic reactions are potentially lifethreatening, ${ }^{10-12}$ with peanuts and tree nuts accounting for $80 \%$ of food-induced fatal anaphylaxis cases. Severe reactions can occur both inside and outside of the home, and victims are often not aware that the products they were eating contained the food allergens.

This review will focus on the immunopathophysiology of food allergy and discusses therapeutic strategies currently being in-

Correspondence to: Julie Wang, M.D., Department of Pediatrics, Box 1198 Mount Sinai School of Medicine, One Gustave L. Levy Place, New York, New York 10029-6574, USA.

Tel: +1-212-241-5548; Fax: +1-212-426-1902; E-mail: Julie.wang@mssm.edu Received: August 12, 2009; Accepted: September 10, 2009

- There are no financial or other issues that might lead to conflict of interest. 
vestigated with the aim of long-term treatment and possible cure of food allergy.

\section{TYPES OF FOOD ALLERGY}

Immune reactions to foods can be IgE-mediated, cell-mediated or result from a combination of IgE and non-IgE mechanisms (Table 1). IgE-mediated reactions occur within 2 hrs of exposure. Binding of food allergens by specific IgE on effector cells, such as basophils and mast cells, leads to mediator release (i.e. histamine, tryptase, cysteinyl leukotrienes, prostaglandin $\mathrm{D}_{2}$ ) causing a variety of symptoms that typically affect the cutaneous, respiratory, gastrointestinal and/or cardiovascular systems. Serum IgE and prick skin testing measure allergen-specific IgE, and these provide an indication of the likelihood of allergic reaction with exposure to the food allergen, however the type of reactions that occur are unpredictable in severity. Predictive values for serum food-specific IgE levels and prick skin testing have been published for the major food allergens, and levels above the $95 \%$ positive predictive value are highly indicative of clinical reactivity. ${ }^{13-17}$ It has also been shown that the rate of decline in food specific IgE levels over time has predictive value for the development of tolerance. ${ }^{18}$

Cell-mediated reactions to foods include food protein-induced enterocolitis syndrome (FPIES) and proctocolitis. FPIES is characterized by repetitive vomiting and diarrhea at least 2 hrs after ingestion of the food trigger, with common ones including milk, soy and grains. Dehydration often occurs, with hypotension and metabolic acidosis ensuing in severe cases. ${ }^{19}$ The immediate treatment for symptoms includes intravenous fluid hydration. As in other food allergies, food avoidance is important. Periodic re-evaluation with physician-supervised oral food challenges are advised to determine whether the allergy has been outgrown. Food protein-induced proctocolitis is commonly triggered by cow's milk and soy, and symptoms can be triggered by exposure through maternal breast milk. Infants are generally brought to medical attention for evaluation of blood streaked stools. These infants are otherwise well in terms of growth and do not generally suffer adverse effects from blood loss, such as anemia. Symptoms resolve with maternal and infant avoidance of milk, and the majority of children outgrow this allergy by 1 yr of age. ${ }^{20}$

Atopic dermatitis and eosinophilic gastroenteropathies are triggered by a combination of IgE and cell-mediated processes. Approximately $35 \%$ of children with moderate-severe atopic dermatitis have food allergies as a trigger. ${ }^{21}$ Removal of culprit foods results in significant improvement in skin symptoms for these children. In an international multicenter study of children with atopic dermatitis, a close association between early-onset, moderate-to-severe eczema and egg sensitization was found. ${ }^{22}$ Children who developed atopic dermatitis after 12 months of age were less likely to have concurrent food allergies.

Table 1. Types of food allergy

\begin{tabular}{|c|c|c|c|c|}
\hline Disorder & Mechanism & Clinical features & Immunopathology & Common food triggers \\
\hline $\begin{array}{l}\text { Urticaria/angioedema, } \\
\text { anaphylaxis }\end{array}$ & $\lg E$ & $\begin{array}{l}\text { Cutaneous, gastrointestinal, } \\
\text { respiratory symptoms }\end{array}$ & $\begin{array}{l}\text { Cross-linking of lgE results in release } \\
\text { of mediators }\end{array}$ & $\begin{array}{l}\text { Major allergens - Milk, egg, } \\
\text { wheat, soy, peanut, tree nuts, } \\
\text { fish and shellfish }\end{array}$ \\
\hline Oral Allergy syndrome & $\lg E$ & $\begin{array}{l}\text { Mild oropharyngeal symptoms } \\
\text { primarily (pruritus, angioedema) }\end{array}$ & $\begin{array}{l}\text { Primary sensitization to pollen } \\
\text { proteins which are homologous to } \\
\text { food proteins in certain fruits/ } \\
\text { vegetables }\end{array}$ & Raw fruits and vegetables \\
\hline $\begin{array}{l}\text { Food-dependent, exercise- } \\
\text { induced anaphylaxis }\end{array}$ & $\lg E$ & $\begin{array}{l}\text { Food triggers anaphylaxis only if } \\
\text { ingestion is followed by exercise }\end{array}$ & $\begin{array}{l}\text { Enhanced mast cell releasability and } \\
\text { altered intestinal permeability when } \\
\text { food ingestion is followed by exercise }\end{array}$ & $\begin{array}{l}\text { Wheat, shellfish and celery are } \\
\text { the most commonly reported } \\
\text { triggers }\end{array}$ \\
\hline Atopic dermatitis & $\begin{array}{l}\text { Mixed } \lg E / \\
\text { non-lgE }\end{array}$ & $\begin{array}{l}\text { Chronic inflammatory skin disease, } \\
\text { pruritic }\end{array}$ & $\begin{array}{l}\text { IgE-mediated activation of cutaneous } \\
\text { mast cells; late phase infiltration of } \\
\text { inflammatory cells, including } \\
\text { eosinophils and T cells }\end{array}$ & $\begin{array}{l}\text { Egg, wheat, milk, soy, and } \\
\text { others }\end{array}$ \\
\hline $\begin{array}{l}\text { Eosinophilic gastroenter- } \\
\text { opathies }\end{array}$ & $\begin{array}{l}\text { Mixed lgE/ } \\
\text { non-lgE }\end{array}$ & $\begin{array}{l}\text { Dysphagia, poor growth, abdominal } \\
\text { complaints (nausea, vomiting) }\end{array}$ & $\begin{array}{l}\text { Eosinophilic infiltration of the } \\
\text { gastrointestinal tract, mediators of } \\
\text { eosinophils play a role (i.e. IL-5, } \\
\text { eotaxin) }\end{array}$ & Multiple foods \\
\hline $\begin{array}{l}\text { Food-protein induced } \\
\text { enterocolitis }\end{array}$ & Non-lgE & $\begin{array}{l}\text { Delayed emesis, diarrhea } 2 \text { hours } \\
\text { following ingestion, severe cases } \\
\text { - hypotension in } 15 \%\end{array}$ & Increased TNF $\alpha$, decreased TGF $\beta$ & Milk, soy, grains \\
\hline $\begin{array}{l}\text { Food-protein induced } \\
\text { proctocolitis }\end{array}$ & Non-lgE & Blood-streaked stools in infants & Eosinophilic infiltration in the colon & $\begin{array}{l}\text { Milk and soy, can occur via } \\
\text { breastmilk }\end{array}$ \\
\hline
\end{tabular}


Allergic eosinophilic esophagitis (AEE) and allergic eosinophilic gastroenteritis (AEG) are inflammatory disorders characterized by high numbers of intraepithelial eosinophils in the gastrointestinal tract. ${ }^{23-25}$ Although the etiology is still unclear, many patients have IgE-mediated food and aeroallergen sensitization. In a series of over 500 people with AEE, the main food triggers were milk, egg, wheat, corn, beef, chicken, barley, oats, rice, and peanuts. ${ }^{26}$ Although the majority of patients responded to elemental diets, only 11 patients experienced resolution of their AEE and eventually resumed an unrestricted diet without medications. Since this is a mixed IgE and cell-mediated process, prick skin testing and serum specific IgE levels may not identify all the allergic triggers. Atopy patch testing has been investigated as an additional diagnostic tool to identify foods that cause delayed symptoms.

\section{MECHANISM OF FOOD ALLERGY}

Normally, there is a delicate balance of the gastrointestinal mucosal immune system distinguishing between potentially harmful pathogens, beneficial commensal bacteria, and harmless food allergens which do not induce active immune responses. The mechanisms by which ingested proteins are able to interact with unique populations of antigen presenting cells leading to suppression of cellular and humoral immune responses has been termed oral tolerance. This has been demonstrated in a murine model in which subcutaneous antigen exposure resulted in cell-mediated and humoral responses to the antigen in vitro, but mice that were first orally exposed to the antigen then immunized subcutaneously had decreased immune responses in vitro. ${ }^{27}$ Transfer of $\mathrm{T}$ cells from the orally fed mice to naïve mice resulted in decreased immune responses as well. Different mechanisms of tolerance can occur depending on the dose of allergen exposure. Studies suggest that "high dose" tolerance is due to deletion of effector T cells, whereas "low dose" tolerance involves activation of regulatory T cells. ${ }^{28}$

Loss of oral tolerance can occur or may be bypassed by antigen presentation via alternative routes, such as through cutaneous exposures or via the respiratory tract. Using a murine model, epicutaneous or epidermal exposure to peanut was demonstrated to induce Th2 immune responses and promoted allergic sensitization..$^{29}$ In addition, higher rates of peanut allergy have been found in children with atopic dermatitis who used topical creams containing peanut oil (OR 6.8). ${ }^{30}$ Respiratory exposures are seen in pollen-food syndrome (PFS), an IgE-mediated allergy that is due to cross-reacting proteins in pollens (the initial sensitizing allergen) and foods, which results in oropharyngeal symptoms to raw fruits and vegetables. ${ }^{31}$

Breakdown of oral tolerance can also occur as a result of defective regulatory $\mathrm{T}$ cells. The disorder of immune dysregulation, polyendocrinopathy, enteropathy, X-linked (IPEX) syndrome is due to a mutation in the FOXP3 gene, a transcription factor on CD4+CD25+ regulatory $\mathrm{T}$ cells that has been implicated in blocking Th1 and Th2 responses. Atopic dermatitis and food allergies are known manifestations of this disorder. ${ }^{32}$ The importance of $\mathrm{T}$ regulatory cells in tolerance was also demonstrated in a study of non-IgE milk allergy. The development of tolerance to milk was associated with higher numbers of circulating $\mathrm{CD} 4+\mathrm{CD} 25+$ regulatory $\mathrm{T}$ cells. ${ }^{33}$

\section{Host factors}

Several host factors can influence the development of food allergies. Different mouse strains are not equally susceptible to food allergies, ${ }^{34,35}$ suggesting that genetic predisposition is important. Furthermore, the age of exposure to food allergens can determine whether tolerance or allergy develops. In a murine model, sensitization occurred when mice were orally fed ovalbumin in the first week of life, however, tolerance was induced when the mice were orally exposed to ovalbumin at 2-3 weeks of age. ${ }^{36}$ In humans, epidemiologic studies show a higher rate of food allergies in young children as compared to adults, ${ }^{1}$ suggesting that gut maturity may be a factor in the development of food allergies. On the other hand, population studies suggest that early introduction may be beneficial in some cases. In Isra$\mathrm{el}$, where infants are fed peanut proteins starting at an early age, there is a lower incidence of peanut allergy as compared to the UK where peanut is not introduced to children until a much later age. ${ }^{37}$ The Learning Early About Peanut Allergies (LEAP) study is currently exploring the role of timing of peanut allergen exposure in the development of peanut allergy.

Several studies suggest that disruption of normal gut barrier functions, such as gastric $\mathrm{pH}$ and commensal bacteria, can increase the risk of food allergies. Gastric digestion normally serves to breakdown food proteins, and in many cases destroys immunogenic epitopes in the process. The role of gastric acidity was investigated by Untersmayr et al. ${ }^{38}$ using a murine model. Mice fed caviar extract in combination with antacids had elevated specific IgE and demonstrated immediate skin reactivity to the protein after immunization. However, mice which were not fed antacids did not demonstrate these immunologic responses, suggesting that use of antacid medications increased the risk of food allergen sensitization. In a human study of 152 patients on antacid treatment for dyspepsia, increased food allergen sensitization was seen in $25 \%$ after 3 months. ${ }^{39}$ Gastric enzymes can affect allergenicity of food proteins. Specifically, the allergenicity of ovomucoid has been demonstrated to be reduced after gastric digestion. ${ }^{40}$ Additionally, commensal bacterial serve an important role. Mice raised in a germ-free environment do not develop normal tolerance, ${ }^{41}$ and mice treated with antibiotics or those lacking in toll like receptor 4 (TLR4) are more easily sensitized to peanut than wild-type control mice. ${ }^{42}$

Additional host factors can modulate the clinical response of food allergy. For example, asthma has been shown to be a risk factor for more severe anaphylaxis. In a study of fatal food aller- 
gic reactions, the majority of victims had underlying asthma. ${ }^{11}$ Host factors such as exercise, use of medication (alcohol, aspirin, beta-blockers, angiotensin converting enzyme inhibitors, monoamine oxidase inhibitors, tricyclic antidepressants), and concurrent infection may increase the severity of anaphylactic reactions or diminish the efficacy of epinephrine. ${ }^{43,44}$ Recently, low serum platelet-activating factor acetylhydrolase (PAF-AH) activity has been found to be a risk factor for more severe foodinduced anaphylaxis. ${ }^{45}$

\section{Food allergen factors}

Food allergies can produce an array of clinical symptoms. The presence of specific IgE to sequential or conformational epitopes can distinguish between different phenotypes of milk and egg allergy. Several studies show that binding of conformational epitopes is associated with transient allergy to milk and egg whereas binding of sequential epitopes in these proteins is a marker for persistent allergy. ${ }^{46,47}$ Recent studies demonstrate that the majority of milk and egg allergic individuals can tolerate extensively heated or baked forms of these foods, ${ }^{15-18}$ indicating that these individuals identify conformational epitopes that are disrupted by heating. Furthermore, studies show that different patterns of epitope recognition or epitope diversity may correlate with clinical manifestations of allergic reactions to peanut and milk. ${ }^{48-51}$

Although heating appears to render many proteins less allergenic, heating does not have the same effect on all food proteins. Roasting peanuts involves very high temperatures, and this causes a Maillard reaction leading to increased stability and allergenicity of peanut allergens. ${ }^{52}$ This finding may explain the differences in prevalence of peanut allergy in the U.S. where peanuts are primarily consumed in the roasted form and China where boiled or fried peanuts predominate.

Additional properties of peanut make it a highly allergenic protein. Glycosylated Ara h 1, a major peanut allergen, has been shown to act as a Th2 adjuvant by activating dendritic cells to drive Th2 cell maturation. ${ }^{53}$ In contrast, deglycoslyated Ara h 1 did not activate dendritic cells. Recently, peanut proteins were shown to have the ability to induce production of complement (C3a) leading to increased platelet-activating factor and histamine production by macrophages, basophils, and mast cells. ${ }^{54}$

\section{THERAPIES}

Since no treatments are available to cure or provide long-term remission from food allergy, there is a strong need to develop effective therapies. Several strategies are currently being inves-

Table 2. Allergen-specific approaches for the treatment of food allergy

\begin{tabular}{|c|c|c|c|c|}
\hline & Mechanism & Effects & Concerns & Research status \\
\hline $\begin{array}{l}\text { Subcutaneous } \\
\text { immunotherapy } \\
\text { (SCIT) }\end{array}$ & $\begin{array}{l}\text { Gradual exposure to allergens to } \\
\text { induce desensitization or tolerance }\end{array}$ & $\begin{array}{l}\text { Proven therapy for respiratory and } \\
\text { venom allergy, equivocal results for } \\
\text { oral allergy syndrome }\end{array}$ & $\begin{array}{l}\text { High risk of anaphylaxis in peanut } \\
\text { allergy studies }\end{array}$ & No current studies \\
\hline $\begin{array}{l}\text { Oral immunotherapy } \\
\text { (OIT) }\end{array}$ & $\begin{array}{l}\text { Gradual exposure to allergens to } \\
\text { induce desensitization or tolerance }\end{array}$ & $\begin{array}{l}\text { Improved clinical tolerance; studies } \\
\text { mainly for milk and egg; recent } \\
\text { double-blind, placebo-controlled } \\
\text { study for milk }\end{array}$ & $\begin{array}{l}\text { Unclear whether the effects are } \\
\text { desensitization or induction of } \\
\text { tolerance; side effects are common }\end{array}$ & Clinical \\
\hline $\begin{array}{l}\text { Sublingual immuno- } \\
\text { therapy (SLIT) }\end{array}$ & $\begin{array}{l}\text { Gradual exposure to allergens to } \\
\text { induce desensitization or tolerance }\end{array}$ & $\begin{array}{l}\text { Improved clinical tolerance; largest } \\
\text { study for hazelnut allergy }\end{array}$ & $\begin{array}{l}\text { Unclear whether the effects are } \\
\text { desensitization or induction of } \\
\text { tolerance; side effects are common }\end{array}$ & Clinical \\
\hline $\begin{array}{l}\text { Recombinant } \\
\text { vaccines }\end{array}$ & $\begin{array}{l}\text { Mutate lgE binding sites; proteins } \\
\text { stimulate T cells to proliferate, but } \\
\text { have greatly reduced lgE-binding } \\
\text { capacity }\end{array}$ & $\begin{array}{l}\text { Protection against peanut anaphy- } \\
\text { laxis in mice; study of Bet v } 1 \text { for } \\
\text { OAS demonstrated improvement of } \\
\text { symptoms }\end{array}$ & $\begin{array}{l}\text { Improved safety profile compared } \\
\text { with conventional IT, requires identi- } \\
\text { fication of IgE binding sites for each } \\
\text { allergen }\end{array}$ & $\begin{array}{l}\text { Preclinical and } \\
\text { clinical }\end{array}$ \\
\hline $\begin{array}{l}\text { Peptide immuno- } \\
\text { therapy }\end{array}$ & $\begin{array}{l}\text { Peptide fragments contain T cell } \\
\text { epitopes, but are not of sufficient } \\
\text { length to cross-link IgE and there- } \\
\text { fore, cannot trigger mast cell or } \\
\text { basophil activation; }\end{array}$ & $\begin{array}{l}\text { Protection against peanut anaphy- } \\
\text { laxis in mice }\end{array}$ & $\begin{array}{l}\text { Improved safety profile compared } \\
\text { with conventional IT, requires identi- } \\
\text { fication of T cell epitopes for each } \\
\text { allergen }\end{array}$ & Preclinical \\
\hline $\begin{array}{l}\text { ISS-conjugated } \\
\text { protein immuno- } \\
\text { therapy }\end{array}$ & $\begin{array}{l}\text { ISS bound to proteins can act as } \\
\text { adjuvants to promote switching to a } \\
\text { Th1 response }\end{array}$ & $\begin{array}{l}\text { Protection against peanut sensitiza- } \\
\text { tion in mice }\end{array}$ & $\begin{array}{l}\text { Concern for excessive Th1 stimula- } \\
\text { tion, and potential for autoimmunity }\end{array}$ & Preclinical \\
\hline $\begin{array}{l}\text { Plasmid DNA } \\
\text { immunotherapy }\end{array}$ & $\begin{array}{l}\text { Allergen gene immunization to } \\
\text { promote endogenous allergen } \\
\text { production resulting in possible } \\
\text { induction of tolerance }\end{array}$ & $\begin{array}{l}\text { Less severe and delayed peanut- } \\
\text { induced anaphylaxis in a murine } \\
\text { model }\end{array}$ & $\begin{array}{l}\text { Serious concerns regarding safety } \\
\text { in view of strain-dependent effects } \\
\text { in mice }\end{array}$ & Preclinical \\
\hline
\end{tabular}


tigated, both allergen-specific (Table 2) and allergen non-specific (Table 3). Allergen-specific approaches attempt to alter the allergic response to specific food allergens, whereas allergen non-specific treatments are aimed at modulating the overall allergic response. These non-specific approaches would be particularly beneficial for individuals suffering from multiple food allergies.

\section{Allergen specific therapies \\ Allergen Immunotherapy}

Immunotherapy entails gradual exposure to allergens in the hope of desensitization (temporary loss of responsiveness due to continuous exposure) and/or promoting tolerance (permanent immunologic nonresponse). Although widely used for respiratory allergies, the mechanisms of immunotherapy are not well understood, but is believed to involve initial desensitization of mast cells and basophils, changes in allergen-specific $\mathrm{T}$ cell responses and/or induction of regulatory $\mathrm{T}$ cells and late effects on effector cells, including eosinophils and B cells. ${ }^{55}$ Food specific immunotherapy has been investigated as a potential treatment for food allergy.

Subcutaneous immunotherapy (SCIT) has been used since 1911, and is highly efficacious for allergic rhinitis, asthma and insect sting allergy ${ }^{56,57}$ However, early attempts at using SCIT for food allergies demonstrated unacceptably high rates of severe adverse reactions. ${ }^{58,59}$ Since pollen-food syndrome (PFS) occurs due to cross-reactivity with pollens, SCIT would seem to be a logical treatment for PFS as well. Although results demonstrate clinical improvements in many patients, these studies lacked appropriate control groups and relied on self-reported symptoms. ${ }^{60,61}$ Furthermore, with difficulties in objective evaluations for improvement in symptoms in PFS and lack of consensus for target doses, SCIT remains an unproven therapeutic approach for PFS.

Given the high rates of adverse reactions with SCIT, alterna- tive routes of administering immunotherapy are being investigated to improve the risk-benefit ratio. There is an expanding body of literature that reports a high rate of efficacy with oral immunotherapy (OIT) (75-86\%) with various food allergens. ${ }^{62}$ The first double-blind, placebo-controlled OIT study for food allergy in children was performed by Skripak et al ${ }^{63}$ for milk allergy. Twelve patients completed 3-4 months of active treatment. Although no significant changes in specific IgE levels or skin prick test results were observed, there was a significant increase in milk-specific IgG and $\operatorname{IgG}_{4}$ in the active group. More importantly, the majority of participants experienced reactions during the post-OIT food challenge, demonstrating that complete protection from allergic reactions due to milk was not achieved. Furthermore, all participants continued daily intake of dairy, therefore, it is unclear whether any OIT participants developed tolerance rather than desensitization to milk.

Additional studies have investigated the effects and safety of OIT in varying patient populations and using different dosing regimens. Longo et al.$^{64}$ reported on their experience with OIT in a highly milk allergic population. After $1 \mathrm{yr}, 36 \%$ of the OIT group had unrestricted diets, and more than half (54\%) were able to tolerate limited amounts of milk (ranging from 5-150 $\mathrm{mL}$ ). Adverse reactions were common and occurred in all children on OIT. This study demonstrated that OIT can be effective even for those with the most severe allergies. The authors noted that although adverse events were common, in cases of persistent milk allergy and a high risk of accidental exposures and reactions, the risks of treatment may be acceptable. Staden et al. ${ }^{65}$ reported a case series of 9 high-risk children who successfully underwent a rush oral immunotherapy protocol with milk, suggesting that desensitization can be achieved quickly. Adverse effects were frequent, but generally mild.

Recently, Jones et al. ${ }^{66}$ reported an open-label peanut oral immunotherapy (OIT) study in which desensitization was successful in $93 \%$ of patients. The authors assessed several immu-

Table 3. Allergen non-specific approaches for the treatment of food allergy

\begin{tabular}{|c|c|c|c|c|}
\hline & Mechanism & Effects & Concerns & Research status \\
\hline Anti-lgE & $\begin{array}{l}\text { Decreases circulating free lgE, inhibits the } \\
\text { early and late phase allergic response, } \\
\text { suppresses inflammation and provides } \\
\text { improved control for allergic diseases }\end{array}$ & $\begin{array}{l}\text { Provided an improved threshold } \\
\text { against peanut-induced reactions in } \\
80 \% \text { of treated patients }\end{array}$ & $\begin{array}{l}\text { May be useful in combina- } \\
\text { tion with immunotherapy }\end{array}$ & Clinical \\
\hline $\begin{array}{l}\text { Chinese herbal } \\
\text { medicine }\end{array}$ & Inhibit Th2 immune response & $\begin{array}{l}\text { Long-term protection from peanut } \\
\text { anaphylaxis in a murine model. Also } \\
\text { effective in murine model of multiple } \\
\text { food allergies }\end{array}$ & $\begin{array}{l}\text { Oral, generally safe and } \\
\text { well tolerated; currently in } \\
\text { Phase I trial }\end{array}$ & Clinical \\
\hline Cytokine/anti-cytokine & Block pro-allergic cytokines & $\begin{array}{l}\text { Clinical improvement in patients with } \\
\text { eosinophilic esophagitis (IL-5) }\end{array}$ & $\begin{array}{l}\text { Concerns for systemic side } \\
\text { effects }\end{array}$ & Clinical \\
\hline TLR-9 & Induction of Th1-type immune responses & $\begin{array}{l}\text { Protect from peanut anaphylaxis in a } \\
\text { murine model }\end{array}$ & $\begin{array}{l}\text { Concern for excessive Th1 } \\
\text { stimulation, and potential } \\
\text { for autoimmunity }\end{array}$ & Preclinical \\
\hline
\end{tabular}


nological parameters and presented several interesting results about possible mechanisms of OIT. Declines in skin prick tests and peanut-specific IgE levels and increases in peanut-specific $\mathrm{IgG}_{4}$ were observed. A significant decrease in basophil activation was detected, as well as increases in several cytokines, including IL-10 and IL-5, which suggests that OIT does not cause the typical downregulation of Th2 and upregulation of Th1 profiles. In addition, T-cell microarrays demonstrated downregulation of apoptotic genes, indicating a potential role for apoptosis in OIT.

Sublingual immunotherapy (SLIT), which has been demonstrated to be a safe and effective treatment for allergic rhinitis and asthma, is another attractive option for the treatment of food allergy. Enrique et al. ${ }^{67}$ published a randomized doubleblind, placebo-controlled study investigating SLIT for hazelnut allergy. Twelve patients with hazelnut allergy (6 with PFS) were treated with SLIT for 5 months using the sublingual-discharge technique. Significant increases in threshold of sensitivity to hazelnut were observed following treatment. There was also an increase in hazelnut-specific IgG $_{4}$ and IL-10 after treatment in the active group. Local reactions occurred in $7.4 \%$ and systemic reactions were low $(0.2 \%)$. A follow-up report of 7 patients from the active treatment group who resumed SLIT 4 months after discontinuation demonstrated tolerance of significantly increased doses of hazelnut, decreased specific IgE, and increased specific $\operatorname{IgG}_{4}$, thus demonstrating the beneficial effect of SLIT even after treatment interruption. ${ }^{68}$ A recent randomized, double-blind, placebo-controlled clinical trial of SLIT for peach allergy also reported promising results of improved allergen tolerance that was associated with decreases in skin test reactivity and significant increases in IgE and IgG $_{4}$ to Pru p $3 .^{69}$

One multicenter study investigated the effects of birch pollen SLIT for PFS. ${ }^{70}$ Twenty patients with pollen-associated apple allergy received $1 \mathrm{yr}$ of SLIT. Although improvement in nasal provocation scores to birch pollen was seen in 9 patients, there was no significant improvement in their apple-induced oral symptoms. In addition, there was no change in specific IgE or $\mathrm{IgG}_{4}$ to the major apple allergen, Mal d 1, after treatment. The authors concluded that SLIT with birch pollen may have no clinical effect on associated apple allergy.

Overall, immunotherapy appears to be a promising option for the treatment of food allergy, especially as safer routes of administration are being investigated. Additional randomized, placebo-controlled trials are necessary to determine the true efficacy and safety of this method and to standardize extracts, protocols and durations of treatment. Furthermore, studies are needed to clarify whether these clinical improvements are due to true induction of oral tolerance or desensitization and to gain insight into the mechanisms of these treatments.

\section{Modified recombinant vaccines}

Modified recombinant food proteins are engineered to de- crease IgE binding capacity while retaining the protein's ability to stimulate $\mathrm{T}$ cell in order to decrease adverse effects of immunotherapy due to allergen activation of mast cells and basophils. Currently, recombinant peanut, ${ }^{71,72}$ apple ${ }^{73}$ and fish $^{74}$ allergens have been generated. Modified peanut allergens (Ara $h$ $1,2,3)$, altered using site-directed mutagenesis, can stimulate $\mathrm{T}$ cells from peanut allergic individuals to proliferate, but have greatly reduced IgE-binding capacity as compared to wild-type peanut protein. ${ }^{71,72}$ Heat-killed E. coli (HKE) producing recombinant peanut proteins have been shown to have protective effects in a murine model of peanut anaphylaxis. ${ }^{75}$ Peanut-sensitized mice treated with HKE containing modified proteins Ara $h$ 1-3 (HKE-MP123) demonstrated reduced symptom scores during peanut challenge as compared to the placebo-treated group. This protection lasted up to 10 weeks post-treatment in the medium and high dose treated groups. The high-dose treated group demonstrated the most significant decrease in IgE levels and decreased production of IL-4, IL-5, IL-13 and IL-10, and increased IFN- $\gamma$ and TGF- $\beta$ production by splenocytes. The mechanisms are hypothesized to involve Thl cytokines and/or T regulatory cells suppressing Th2 cell activation and mast cell/ basophil mediator release on re-exposure to antigen. ${ }^{76,77} \mathrm{Clini}$ cal trials are planned.

SCIT with modified birch pollen allergens (Bet v 1 fragments, Bet $\mathrm{v} 1$ trimer) has been shown to be moderately effective for patients with PFS. ${ }^{78}$ Seven, out of 25 patients on active treatment, reported improvement in their oral symptoms as compared to only 1 of 19 placebo-treated patients.

\section{Peptide immunotherapy}

Use of peptide fragments that contain $\mathrm{T}$ cell epitopes that are not of sufficient length to cross-link IgE, is another potential strategy to decrease adverse effects of immunotherapy related to mast cell or basophil activation. A preliminary in vitro study using pepsin-digested peanut peptides showed induction of IFN- $\gamma$ (Thl cytokine) from peripheral blood mononuclear cells in a concentration-dependent manner. ${ }^{79}$ In a murine model of peanut allergy, mice receiving immunotherapy with peptides containing IgE epitopes to the major peanut protein Ara h 2 prior to allergen challenge experienced only mild allergic reactions as compared to sham-treated mice, which exhibited severe anaphylactic reactions. ${ }^{80}$ Although these preliminary murine studies are promising, validating the stability and uniformity of peptide mixtures for human use poses a significant challenge.

\section{Immunostimulatory sequence-conjugated protein immunotherapy}

Immunostimulatory sequences (ISS), such as CpG oligodeoxynucleotides, bound to proteins can act as adjuvants to promote switching to a Th1 response, ${ }^{81}$ thus making the proteins less allergenic. Early studies using ragweed allergen showed 
that immunotherapy with ISS in combination with Amb a 1, the major ragweed allergen, promoted Thl responses and reduced allergenicity in mice, rabbit and primates ${ }^{82}$ The mice then underwent a sensitization protocol to beta-gal. Similarly, mice immunized with beta-galactosidase plus an ISS sequence oligodeoxynucleotide were protected from developing fatal anaphylaxis and had lower plasma histamine levels after allergen challenge compared to the group treated with beta-gal protein alone. ${ }^{83}$

A similar approach was investigated in a murine model of peanut-induced anaphylaxis. ${ }^{84}$ Mice treated with ISS-linked Ara h 2 (a major peanut protein) had lower symptoms scores and lower plasma histamine levels following challenge with Ara $\mathrm{h} 2$ compared to the mice treated with ISS-linked Amb a 1. A significantly higher Ara h 2-specific IgG2a levels in the ISS-linked Ara h 2 treated mice was seen, but there was no significant difference in specific-IgE or $\operatorname{IgG}_{1}$ levels between the two groups. These findings suggest that ISS-conjugated protein immunotherapy may be an effective treatment for food allergy.

\section{Plasmid DNA immunotherapy}

Allergen gene immunization is another approach to immunomodulate the allergic response. DNA nanoparticles containing the gene for Ara $\mathrm{h} 2$ was synthesized by complexing plasmid DNA with chitosan and then administered these nanoparticles orally to mice. ${ }^{85}$ Immunized mice demonstrated less severe and delayed anaphylactic responses following challenge compared to mice treated with 'naked' DNA or unimmunized mice, and this was associated with decreased IgE levels, lower plasma histamine, and less vascular leakage. Despite promising results in the murine model, concerns regarding use in humans are a potential disadvantage of this technique.

\section{Allergen non-specific therapies}

\section{Anti-IgE}

Approved for the treatment of asthma with associated environmental allergies, recombinant monoclonal humanized antiIgE treatment causes decreased circulating free IgE, inhibits the early and late phase allergic response, suppresses inflammation and provides improved control for allergic diseases. ${ }^{86} \mathrm{~A}$ double-blind, randomized, dose-ranging trial in 84 patients with a history of peanut allergy was the first investigation of this for the management of food allergy ${ }^{87}$ Patients were randomized to receive either TNX-901 (150, 300, or $450 \mathrm{mg}$ of anti-IgE antibodies) or placebo for 4 months. Patients receiving the highest dose experienced significant decreases in symptoms with peanut challenge as compared to the placebo group. The median threshold of sensitivity to peanut increased from 178 mg peanut protein (the equivalent to one peanut) to almost 9 peanuts (2.8 grams). Although $25 \%$ of patients were able to tolerate over 20 peanuts post-treatment, another $25 \%$ failed to develop any change in tolerance to peanut indicating that the treatment response can be variable. Investigation of another anti-IgE preparation, omalizumab (Xolair ${ }^{\circledR}$, Genentech), for the treatment of peanut allergy was initiated, but discontinued for safety issues related to the protocol. ${ }^{88}$

Combination therapy of anti-IgE and allergen immunotherapy is being investigated as a method to decrease adverse reactions to immunotherapy in order to allow increased safety and efficacy ${ }^{89}$ No data is currently available regarding the effectiveness of this strategy.

\section{Chinese herbal medicine}

A 9-herb formula based on Traditional Chinese Medicine is currently under investigation as a treatment of food allergy. It is named the food allergy herbal formula (FAHF-2) and is effective in a murine model of peanut-induced anaphylaxis. ${ }^{90} \mathrm{Pea}-$ nut-allergic mice treated with FAHF-2 had no signs of anaphylaxis after peanut challenge, but all sham-treated mice had severe symptoms of anaphylaxis, decreased rectal temperatures, elevated plasma histamine, and marked vascular leakage. There were also associated decreases in peanut-specific IgE levels and Th2 cytokine production (IL-4, IL-5, IL-13). The protective effects of FAHF-2 were demonstrated to last up to 6 months post-therapy, which represents about $25 \%$ of the lifespan of the mouse. ${ }^{91}$ Furthermore, these effects are not peanutspecific; treatment has been shown to modulate the allergic response in a murine model of multiple food allergies. ${ }^{92}$

Peliminary studies with purified human peripheral blood mononuclear cells from peanut-allergic individuals showed that cells stimulated with crude peanut extract in the presence of FAHF-2 had a decrease in antigen-dependent T-cell proliferation. A dose-dependent decrease in Th2 cytokine production (IL-5 and IL-13) and increase in IFN- $\gamma$ production were also seen, indicating that FAHF-2 specifically inhibits the Th2 response. ${ }^{93}$ Recently, the U.S. FDA approved a botanical drug IND for FAHF-2 and a Phase I trial is currently underway.

\section{Cytokine/Anti-cytokine}

Allergic diseases develop in part because of imbalances in $\mathrm{T}$ helper (Th) type 1 and type 2 cytokines. Strategies to block proallergic cytokines have been investigated as potential therapeutic approaches. Use for management of allergic asthma has been most widely investigated, however, applications in the field of food allergies are emerging.

Eosinophilic esophagitis (EE) is a inflammatory disorder characterized by high numbers of intraepithelial eosinophils in the esophagus. ${ }^{23-25}$ Data from murine models of EE and analysis of human esophageal tissue demonstrate the presence of $\mathrm{T}$ cells and mast cells along with eosinophils, indicating that a $\mathrm{Th} 2$-based inflammatory process is a key feature of EE ${ }^{94,95}$ Since IL-5, a major Th2 cytokine, is a regulator of eosinophil function and survival, anti-IL-5 (mepolizumab) has been investigated as a treatment for EE. ${ }^{96}$ Promising results were seen in an open-la- 
bel phase I/II study of anti-IL-5 in 4 adults with EE. Decreases in peripheral and esophageal eosinophilia and symptomatic improvement were seen after 3 monthly infusions of anti-IL-5 (750 mg intravenously).

Recombinant IL- 12 has also been investigated for the treatment of allergic disorders because IL-12 promotes the development of Th1 effector cells and inhibits Th2 class switching. Beneficial effects of reducing blood and sputum eosinophil numbers in asthmatic patients have been seen, however, significant systemic toxicities pose a significant barrier to use ${ }^{97} \mathrm{~A}$ less toxic route of intranasal administration of IL-12 using the nonpathogenic lactic acid bacteria (Lactococcus lactis) as a vehicle has been investigated in a murine model. Pretreatment of mice with $L$. lactis strains expressing bovine-lactoglobulin (BLG) with an IL-12-producing $L$. lactis protected sensitized mice against intranasal challenge with BLG antigen. ${ }^{98}$

\section{Toll-like receptors}

Since stimulation of toll-like receptor 9 (TLR9) can lead to strong mucosal and systemic Thl-type immune responses, the effects of a synthetic TLR9 agonist has been investigated in a murine model of food allergy. ${ }^{99}$ After oral administration, decreased gastrointestinal inflammation and protection from peanut-induced anaphylaxis was observed during or after peanut sensitization. Decreases in IgE and increases in IgG2a levels were also detected. The authors postulated that these effects were due to TLR9 agonist induction of Th1-type immune responses.

\section{Additional strategies currently being investigated for other allergic disorders}

A novel human immunoglobulin Fc-Fc fusion protein, crosslinking the high-affinity FcRI and low-affinity FcRIIb on mast cells and basophils leading to inhibition of degranulation, has been developed. ${ }^{100}$ The same group has also developed a human gamma-allergen fusion protein to achieve the same inhibition in an allergen-specific manner. ${ }^{101}$ The Fc-Fel d 1 fusion protein inhibited Fel d 1-mediated degranulation in purified human basophils from cat allergic patients and blocked the allergic responses in a mouse model. Since many food allergens are already well-characterized, a similar approach can be taken for food allergy.

\section{CONCLUSIONS}

We are continuing to gain more insight into the immune mechanisms leading to the loss of oral tolerance and development of food allergies. A complex combination of host factors and food allergen properties interact to determine whether tolerance or allergy develops in a given individual. With increased knowledge of these various factors, potential treatments can be developed. Currently, a variety of promising therapeutic strate- gies are being investigated. These, either alone or in combination, will hopefully provide long-term treatment options and potentially a cure for food allergy.

\section{ACKNOWLEDGMENTS}

This work was funded in part by a grant from the National Institutes of Health/National Institute of Allergy and Infectious Diseases; K23 AI083883-01.

\section{REFERENCES}

1. Rona RJ, Keil T, Summers C, Gislason D, Zuidmeer L, Sodergren E, Sigurdardottir ST, Lindner T, Goldhahn K, Dahlstrom J, McBride D, Madsen C. The prevalence of food allergy: a meta-analysis. J Allergy Clin Immunol 2007;120:638-46.

2. Sicherer SH, Munoz-Furlong A, Sampson HA. Prevalence of peanut and tree nut allergy in the United States determined by means of a random digit dial telephone survey: a 5-year follow-up study. J Allergy Clin Immunol 2003;112:1203-7.

3. Grundy J, Matthews S, Bateman B, Dean T, Arshad SH. Rising prevalence of allergy to peanut in children: Data from 2 sequential cohorts. J Allergy Clin Immunol 2002;110:784-9.

4. Skripak JM, Matsui EC, Mudd K, Wood RA. The natural history of IgE-mediated cow's milk allergy. J Allergy Clin Immunol 2007; 120:1172-7.

5. Savage JH, Matsui EC, Skripak JM, Wood RA. The natural history of egg allergy. J Allergy Clin Immunol 2007;120:1413-7.

6. Skolnick HS, Conover-Walker MK, Koerner CB, Sampson HA, Burks W, Wood RA. The natural history of peanut allergy. J Allergy Clin Immunol 2001;107:367-74.

7. Fleischer DM, Conover-Walker MK, Matsui EC, Wood RA. The natural history of tree nut allergy. J Allergy Clin Immunol 2005; 116:1087-93.

8. Yu JW, Kagan R, Verreault N, Nicolas N, Joseph L, St Pierre Y, Clarke A. Accidental ingestions in children with peanut allergy. J Allergy Clin Immunol 2006;118:466-72.

9. Cohen BL, Noone S, Munoz-Furlong A, Sicherer SH. Development of a questionnaire to measure quality of life in families with a child with food allergy. J Allergy Clin Immunol 2004;114:1159-63.

10. Sampson HA, Mendelson L, Rosen JP. Fatal and near-fatal anaphylactic reactions to food in children and adolescents. N Engl J Med 1992;327:380-4.

11. Bock SA, Munoz-Furlong A, Sampson HA. Fatalities due to anaphylactic reactions to foods. J Allergy Clin Immunol 2001;107:191-3.

12. Bock SA, Munoz-Furlong A, Sampson HA. Further fatalities caused by anaphylactic reactions to food, 2001-2006. J Allergy Clin Immunol 2007;119:1016-8.

13. Sampson HA. Utility of food-specific IgE concentrations in predicting symptomatic food allergy. J Allergy Clin Immunol 2001; 107:891-6

14. Perry TT, Matsui EC, Kay Conover-Walker M, Wood RA. The relationship of allergen-specific IgE levels and oral food challenge outcome. J Allergy Clin Immunol 2004;114:144-9.

15. Garcia-Ara C, Boyano-Martinez T, Diaz-Pena JM, Martin-Munoz F, Reche-Frutos M, Martin-Esteban M. Specific IgE levels in the diagnosis of immediate hypersensitivity to cows' milk protein in the in- 
fant. J Allergy Clin Immunol 2001;107:185-90.

16. Boyano Martinez T, Garcia-Ara C, Diaz-Pena JM, Munoz FM, Garcia Sanchez G, Esteban MM. Validity of specific IgE antibodies in children with egg allergy. Clin Exp Allergy 2001;31:1464-9.

17. Hill DJ, Heine RG, Hosking CS. The diagnostic value of skin prick testing in children with food allergy. Pediatr Allergy Immunol 2004;15:435-41.

18. Shek LP, Soderstrom L, Ahlstedt S, Beyer K, Sampson HA. Determination of food specific IgE levels over time can predict the development of tolerance in cow's milk and hen's egg allergy. J Allergy Clin Immunol 2004;114:387-91.

19. Nowak-Wegrzyn A, Muraro A. Food protein-induced enterocolitis syndrome. Curr Opin Allergy Clin Immunol 2009;9:371-7.

20. Lake AM, Whitington PF, Hamilton SR. Dietary protein-induced colitis in breast fed infants. J Pediatr 1982;101:906-10.

21. Sicherer SH, Sampson HA. Food hypersensitivity and atopic dermatitis: pathophysiology, epidemiology, diagnosis, and management. J Allergy Clin Immunol 1999;104:S114-22.

22. Hill DJ, Hosking CS, de Benedictis FM, Oranje AP, Diepgen TL, Bauchau V; EPAAC Study Group. Confirmation of the association between high levels of immunoglobulin $\mathrm{E}$ food sensitization and eczema in infancy: an international study. Clin Exp Allergy 2008; 38:161-8.

23. Liacouras CA, Spergel JM, Ruchelli E, Verma R, Mascarenhas M, Semeao E, Flick J, Kelly J, Brown-Whitehorn T, Mamula P, Markowitz JE. Eosinophilic esophagitis: a 10-year experience in 381 children. Clin Gastroenterol Hepatol 2005;3:1198-206.

24. Spergel JM, Beausoleil JL, Mascarenhas M, Liacouras CA. The use of skin prick tests and patch tests to identify causative foods in eosinophilic esophagitis. J Allergy Clin Immunol 2002;109:363-8.

25. Noel RJ, Putnam PE, Rothenberg ME. Eosinophilic esophagitis. N Engl J Med 2004;351:940-1.

26. Spergel JM, Brown-Whitehorn TF, Beausoleil JL, Franciosi J, Shuker M, Verma R, Liacouras CA. 14 years of eosinophilic esophagitis: clinical features and prognosis. J Pediatr Gastroenterol Nutr 2009; 48:30-6.

27. Chase MW. Inhibition of experimental drug allergy by prior feeding of the sensitizing agent. Proc Soc Exp Biol Med 1946;61: 257-9.

28. Chehade M, Mayer L. Oral tolerance and its relation to food hypersensitivities. J Allergy Clin Immunol 2005;115:3-12.

29. Strid J, Thomson M, Hourihane J, Kimber I, Strobel S. A novel model of sensitization and oral tolerance to peanut protein. Immunology 2004;113:293-303.

30. Lack G, Fox D, Northstone K, Golding J; Avon Longitudinal Study of Parents and Children Study Team. Factors associated with the development of peanut allergy in childhood. N Engl J Med 2003; 348:977-85.

31. Bohle B. The impact of pollen-related food allergens on pollen allergy. Allergy 2007;62:3-10.

32. Torgerson TR, Ochs HD. Immune dysregulation, polyendocrinopathy, enteropathy, X-linked: forkhead box protein 3 mutations and lack of regulatory T cells. J Allergy Clin Immunol 2007;120:744-50.

33. Karlsson MR, Rugtveit J, Brandtzaeg P. Allergen-responsive CD4+ CD25+ regulatory $\mathrm{T}$ cells in children who have outgrown cow's milk allergy. J Exp Med 2004;199:1679-88.

34. Li X, Huang CK, Schofield BH, Burks AW, Bannon GA, Kim KH, Huang SK, Sampson HA. Strain-dependent induction of allergic sensitization caused by peanut allergen DNA immunization in mice. J Immunol 1999;162:3045-52.
35. Morafo V, Srivastava K, Huang CK, Kleiner G, Lee SY, Sampson HA, $\mathrm{Li}$ AM. Genetic susceptibility to food allergy is linked to differential TH2-TH1 responses in C3H/HeJ and BALB/c mice. J Allergy Clin Immunol 2003;111:1122-8.

36. Strobel S, Mowat AM. Oral tolerance and allergic responses to food proteins. Curr Opin Allergy Clin Immunol 2006;6:207-13.

37. Du Toit G, Katz Y, Sasieni P, Mesher D, Maleki SJ, Fisher HR, Fox AT, Turcanu V, Amir T, Zadik-Mnuhin G, Cohen A, Livne I, Lack G. Early consumption of peanuts in infancy is associated with a low prevalence of peanut allergy. J Allergy Clin Immunol 2008;122:98491.

38. Untersmayr E, Scholl I, Swoboda I, Beil WJ, Forster-Waldl E, Walter F, Riemer A, Kraml G, Kinaciyan T, Spitzauer S, Boltz-Nitulescu G, Scheiner O, Jensen-Jarolim E. Antacid medication inhibits digestion of dietary proteins and causes food allergy: a fish allergy model in Balb/c mice. J Allergy Clin Immunol 2003;112:616-23.

39. Untersmayr E, Bakos N, Scholl I, Kundi M, Roth-Walter F, Szalai K, Riemer AB, Ankersmit HJ, Scheiner O, Boltz-Nitulescu G, JensenJarolim E. Anti-ulcer drugs promote IgE formation toward dietary antigens in adult patients. FASEB J 2005;19:656-8.

40. Takagi K, Teshima R, Okunuki H, Itoh S, Kawasaki N, Kawanishi T, Hayakawa T, Kohno Y, Urisu A, Sawada J. Kinetic analysis of pepsin digestion of chicken egg white ovomucoid and allergenic potential of pepsin fragments. Int Arch Allergy Immunol 2005;136:23-32.

41. Sudo N, Sawamura S, Tanaka K, Aiba Y, Kubo C, Koga Y. The requirement of intestinal bacterial flora for the development of an IgE production system fully susceptible to oral tolerance induction. J Immunol 1997;159:1739-45.

42. Bashir ME, Louie S, Shi HN, Nagler-Anderson C. Toll-like receptor 4 signaling by intestinal microbes influences susceptibility to food allergy. J Immunol 2004;172:6978-87.

43. Pumphrey R. Anaphylaxis: can we tell who is at risk of a fatal reaction? Curr Opin Allergy Clin Immunol 2004;4:285-90.

44. Miller MM, Miller MM. Beta-blockers and anaphylaxis: are the risks overstated? J Allergy Clin Immunol 2005;116:931-3; author reply 933-6.

45. Vadas P, Gold M, Perelman B, Liss GM, Lack G, Blyth T, Simons FE, Simons KJ, Cass D, Yeung J. Platelet-activating factor, PAF acetylhydrolase, and severe anaphylaxis. N Engl J Med 2008;358:28-35.

46. Jarvinen KM, Beyer K, Vila L, Chatchatee P, Busse PJ, Sampson HA. B-cell epitopes as a screening instrument for persistent cow's milk allergy. J Allergy Clin Immunol 2002;110:293-7.

47. Jarvinen KM, Beyer K, Vila L, Bardina L, Mishoe M, Sampson HA. Specificity of IgE antibodies to sequential epitopes of hen's egg ovomucoid as a marker for persistence of egg allergy. Allergy 2007; 62:758-65

48. Shreffler WG, Lencer DA, Bardina L, Sampson HA. IgE and IgG4 epitope mapping by microarray immunoassay reveals the diversity of immune response to the peanut allergen, Ara h 2. J Allergy Clin Immunol 2005;116:893-9.

49. Wang J, Bardina L, Lencer DA, Shreffler WG, Sampson HA. Determination of epitope diversity in cow's milk hypersensitivity using microarray immunoassay. J Allergy Clin Immunol 2006;117:S39.

50. Flinterman AE, Knol EF, Lencer DA, Bardina L, den Hartog Jager CF, Lin J, Pasmans SG, Bruijnzeel-Koomen CA, Sampson HA, van Hoffen E, Shreffler WG. Peanut epitopes for IgE and IgG4 in peanut-sensitized children in relation to severity of peanut allergy. J Allergy Clin Immunol 2008;121:737-43.

51. Cerecedo I, Zamora J, Shreffler WG, Lin J, Bardina L, Dieguez MC, 
Wang J, Muriel A, de la Hoz B, Sampson HA. Mapping of the IgE and IgG4 sequential epitopes of milk allergens with a peptide microarray-based immunoassay. J Allergy Clin Immunol 2008;122: 589-94.

52. Beyer K, Morrow E, Li XM, Bardina L, Bannon GA, Burks AW, Sampson HA. Effects of cooking methods on peanut allergenicity. J Allergy Clin Immunol 2001;107:1077-81.

53. Shreffler WG, Castro RR, Kucuk ZY, Charlop-Powers Z, Grishina G, Yoo S, Burks AW, Sampson HA. The major glycoprotein allergen from Arachis hypogaea, Ara h 1, is a ligand of dendritic cell-specific ICAM-grabbing nonintegrin and acts as a Th2 adjuvant in vitro. J Immunol 2006;177:3677-85.

54. Khodoun M, Strait R, Orekov T, Hogan S, Karasuyama H, Herbert DR, Kohl J, Finkelman FD. Peanuts can contribute to anaphylactic shock by activating complement. J Allergy Clin Immunol 2009; 123:342-51.

55. Akdis M, Akdis CA. Mechanisms of allergen-specific immunotherapy. J Allergy Clin Immunol 2007;119:780-91.

56. Joint Task Force on Practice Parameters. Allergen immunotherapy: a practice parameter. American Academy of Allergy, Asthma and Immunology. American College of Allergy, Asthma and Immunology. Ann Allergy Asthma Immunol 2003;90(Suppl 1):1-40.

57. Saltoun C, Avila PC. Advances in upper airway diseases and allergen immunotherapy in 2007. J Allergy Clin Immunol 2008;122: 481-7.

58. Oppenheimer JJ, Nelson HS, Bock SA, Christensen F, Leung DYM. Treatment of peanut allergy with rush immunotherapy. J Allergy Clin Immunol 1992;90:256-62.

59. Nelson HS, Lahr J, Rule R, Bock A, Leung D. Treatment of anaphylactic sensitivity to peanuts by immunotherapy with injections of aqueous peanut extract. J Allergy Clin Immunol 1997;99:744-51.

60. Alonso R, Enrique E, Pineda F, Basagana M, San Miguel-Moncin MM, Bartra J, Palacios R, Cistero-Bahima A. An observational study on outgrowing food allergy Turing non-birch pollen-specific, subcutaneous immunotherapy. Int Arch Allergy Immunol 2007; 143:185-9.

61. Czarnecka-Operacz M, Jenerowicz D, Silny W. Oral allergy syndrome in patients with airborne pollen allergy treated with specific immunotherapy. Acta Dermatovenerol Croat 2008;16:19-24.

62. Wang J, Sicherer SH. Immunologic therapeutic approaches in the management of food allergy. Expert Rev Clin Immunol 2009; 5:301-10.

63. Skripak JM, Nash SD, Rowley H, Brereton NH, Oh S, Hamilton RG, Matsui EC, Burks AW, Wood RA. A randomized, double-blind, placebo-controlled study of milk oral immunotherapy for cow's milk allergy. J Allergy Clin Immunol 2008;122:1154-60.

64. Longo G, Barbi E, Berti I, Meneghetti R, Pittalis A, Ronfani L, Ventura A. Specific oral tolerance induction in children with very severe cow's milk-induced reactions. J Allergy Clin Immunol 2008; 121:343-7.

65. Staden U, Blumchen K, Blankenstein N, Dannenberg N, Ulbricht H, Dobberstein K, Ziegert M, Niggemann B, Wahn U, Beyer K. Rush oral immunotherapy in children with persistent cow's milk allergy. J Allergy Clin Immunol 2008;122:418-9.

66. Jones SM, Pons L, Roberts JL, Scurlock AM, Perry TT, Kulis M, Shreffler WG, Steele P, Henry KA, Adair M, Francis JM, Durham S, Vickery BP, Zhong X, Burks AW. Clinical efficacy and immune regulation with peanut oral immunotherapy. J Allergy Clin Immunol 2009;124:292-300.
67. Enrique E, Pineda F, Malek T, Bartra J, Basagana M, Tella R, Castello JV, Alonso R, de Mateo JA, Cerda-Trias T, San Miguel-Moncin Mdel M, Monzon S, Garcia M, Palacios R, Cistero-Bahima A. Sublingual immunotherapy for hazelnut food allergy: a randomized, double-blind, placebo-controlled study with a standardized hazelnut extract. J Allergy Clin Immunol 2005;116:1073-9.

68. Enrique E, Malek T, Pineda F, Palacios R, Bartra J, Tella R, Basagana M, Alonso R, Cistero-Bahima A. Sublingual immunotherapy for hazelnut food allergy: a follow-up study. Ann Allergy Asthma Immunol 2008;100:283-4.

69. Fernandez-Rivas M, Garrido Fernandez S, Nadal JA, Diaz de Durana MD, Garcia BE, Gonzalez-Mancebo E, Martin S, Barber D, Rico P, Tabar AI. Randomized double-blind, placebo-controlled trial of sublingual immunotherapy with a Pru p 3 quantified peach extract. Allergy 2009;64:876-83.

70. Kinaciyan T, Jahn-Schmid B, Radakovics A, Zwolfer B, Schreiber C, Francis JN, Ebner C, Bohle B. Successful sublingual immunotherapy with birch pollen has limited effects on concomitant food allergy to apple and the immune response to the Bet $\mathrm{v} 1$ homolog Mal d 1. J Allergy Clin Immunol 2007;119:937-43.

71. King N, Helm R, Stanley JS, Vieths S, Luttkopf D, Hatahet L, Sampson H, Pons L, Burks W, Bannon GA. Allergenic characteristics of a modified peanut allergen. Mol Nutr Food Res 2005;49: 963-71.

72. Bannon GA, Cockrell G, Connaughton C, West CM, Helm R, Stanley JS, King N, Rabjohn P, Sampson HA, Burks AW. Engineering, characterization and in vitro efficacy of the major peanut allergens for use in immunotherapy. Int Arch Allergy Immunol 2001;124:70-2.

73. Ma Y, Gadermaier G, Bohle B, Bolhaar S, Knulst A, Markovic-Housley Z, Breiteneder H, Briza P, Hoffmann-Sommergruber K, Ferreira F. Mutational analysis of amino acid positions crucial for IgEbinding epitopes of the major apple (Maldus domestica) allergen, Mal d 1. Int Arch Allergy Immunol 2006;139:53-62.

74. Swoboda I, Bugajska-Schretter A, Linhart B, Verdino P, Keller W, Schulmeister U, Sperr WR, Valent P, Peltre G, Quirce S, Douladiris N, Papadopoulos NG, Valenta R, Spitzauer S. A recombinant hypoallergenic parvalbumin mutant for immunotherapy of IgE-mediated fish allergy. J Immunol 2007;178:6290-6.

75. Li XM, Srivastava K, Grishin A, Huang CK, Schofield B, Burks W, Sampson HA. Persistent protective effect of heat-killed Escherichia coli producing "engineered," recombinant peanut proteins in a murine model of peanut allergy. J Allergy Clin Immunol 2003;112: 159-67.

76. Bissonnette EY, Befus AD. Inhibition of mast cell-mediated cytotoxicity by IFN-alpha/beta and -gamma. J Immunol 1990;145: 3385-90.

77. Pierkes M, Bellinghausen I, Hultsch T, Metz G, Knop J, Saloga J. Decreased release of histamine and sulfidoleukotrienes by human peripheral blood leukocytes after wasp venom immunotherapy is partially due to induction of IL-10 and IFN-gamma production of T cells. J Allergy Clin Immunol 1999;103:326-32.

78. Niederberger V, Reisinger J, Valent P, Krauth MT, Pauli G, van Hage M, Cromwell O, Horak F, Valenta R. Vaccination with genetically modified birch pollen allergens: immune and clinical effects on oral allergy syndrome. J Allergy Clin Immunol 2007;119:1013-6.

79. Hong SJ, Michael JG, Fehringer A, Leung DY. Pepsin-digested peanut contains T-cell epitopes but no IgE epitopes. J Allergy Clin Immunol 1999;104:473-8.

80. Li S, Li XM, Burks AW, Bannon GA, Sampson HA. Modulation of 
peanut allergy by peptide-based immunotherapy. J Allergy Clin Immunol 2001;107:S233.

81. Chu RS, Targoni OS, Krieg AM, Lehmann PV, Harding CV. CpG oligodeoxynucleotides act as adjuvants that switch on T helper 1 (Th1) immunity. J Exp Med 1997;186:1623-31.

82. Tighe H, Takabayashi K, Schwartz D, Van Nest G, Tuck S, Eiden JJ, Kagey-Sobotka A, Creticos PS, Lichtenstein LM, Spiegelberg HL, Raz E. Conjugation of immunostimulatory DNA to the short ragweed allergen Amb a 1 enhances its immunogenicity and reduces its allergenicity. J Allergy Clin Immunol 2000;106:124-34.

83. Horner AA, Nguyen MD, Ronaghy A, Cinman N, Verbeek S, Raz E. DNA-based vaccination reduces the risk of lethal anaphylactic hypersensitivity in mice. J Allergy Clin Immunol 2000;106:349-56.

84. Srivastava K, Li XM, Bannon GA, Burks AW, Eiden J, Vannest G, Tuck R, Rodriguez R, Sampson HA. Investigation of the use of Isslinked Ara h2 for the treatment of peanut-induced allergy. J Allergy Clin Immunol 2001;107:S233.

85. Roy K, Mao HQ, Huang SK, Leong KW. Oral gene delivery with chitosan--DNA nanoparticles generates immunologic protection in a murine model of peanut allergy. Nat Med 1999;5:387-91.

86. Milgrom H. Anti-IgE therapy in allergic disease. Curr Opin Pediatr 2004;16:642-7.

87. Leung DY, Sampson HA, Yunginger JW, Burks AW Jr, Schneider LC, Wortel CH, Davis FM, Hyun JD, Shanahan WR Jr; Avon Longitudinal Study of Parents and Children Study Team. Effect of antiIgE therapy in patients with peanut allergy. N Engl J Med 2003;348: 986-93.

88. Sampson HA. A phase II, randomized, double-blind, parallel group, placebo-controlled oral food challenge trial of Xolair (omalizumab) in peanut allergy. J Allergy Clin Immunol 2007;119:S117.

89. Casale TB, Busse WW, Kline JN, Ballas ZK, Moss MH, Townley RG, Mokhtarani M, Seyfert-Margolis V, Asare A, Bateman K, Deniz Y; Immune Tolerance Network Group. Omalizumab pretreatment decreases acute reactions after rush immunotherapy for ragweedinduced seasonal allergic rhinitis. J Allergy Clin Immunol 2006;117: 134-40.

90. Srivastava KD, Kattan JD, Zou ZM, Li JH, Zhang L, Wallenstein S, Goldfarb J, Sampson HA, Li XM. The Chinese herbal medicine formula FAHF-2 completely blocks anaphylactic reactions in a murine model of peanut allergy. J Allergy Clin Immunol 2005;115:171-8.

91. Srivastava KD, Zhang T, Qu C, Sampson HA, Li XM. Silencing peanut allergy: A Chinese Herbal Formula, Fahf-2, completely blocks peanut-induced anaphylaxis for up to 6 months following therapy in a murine model of peanut allergy. J Allergy Clin Immunol 2006; 117:S328.

92. Srivastava KD, Sampson HA, Li XM. The traditional Chinese medicine formula FAHF-2 provides complete protection from anaphylaxis in a murine model of multiple food allergy. J Allergy Clin Immunol 2009;123:S151.

93. Ko J, Busse PJ, Shek L, Noone SA, Sampson HA, Li XM. Effect of Chinese herbal formulas on T-cell responses in patients with peanut allergy or asthma [abstract]. J Allergy Clin Immunol 2005; 115:S34.

94. Mishra A, Hogan SP, Brandt EB, Rothenberg ME. An etiological role for aeroallergens and eosinophils in experimental esophagitis. J Clin Invest 2001;107:83-90.

95. Straumann A, Bauer M, Fischer B, Blaser K, Simon HU. Idiopathic eosinophilic esophagitis is associated with a $\mathrm{T}(\mathrm{H}) 2$-type allergic inflammatory response. J Allergy Clin Immunol 2001;108:954-61.

96. Stein ML, Collins MH, Villanueva JM, Kushner JP, Putnam PE, Buckmeier BK, Filipovich AH, Assa'ad AH, Rothenberg ME. AntiIL-5 (mepolizumab) therapy for eosinophilic esophagitis. J Allergy Clin Immunol 2006;118:1312-9.

97. Bryan SA, O'Connor BJ, Matti S, Leckie MJ, Kanabar V, Khan J, Warrington SJ, Renzetti L, Rames A, Bock JA, Boyce MJ, Hansel TT, Holgate ST, Barnes PJ. Effects of recombinant human interleukin-12 on eosinophils, airway hyper-responsiveness, and the late asthmatic response. Lancet 2000;356:2149-53.

98. Cortes-Perez NG, Ah-Leung S, Bermudez-Humaran LG, Corthier G, Wal JM, Langella P, Adel-Patient K. Intranasal coadministration of live lactococci producing interleukin-12 and a major cow's milk allergen inhibits allergic reaction in mice. Clin Vaccine Immunol 2007;14:226-33.

99. Zhu FG, Kanimalla ER, Yu D, Sgarwal S. Oral administration of a synthetic agonist of Toll-like receptor 9 potently modulates peanut-induced allergy in mice. J Allergy Clin Immunol 2007;120:6317.

100. Zhu D, Kepley CL, Zhang M, Zhang K, Saxon A. A novel human immunoglobulin Fc gamma Fc epsilon bifunctional fusion protein inhibits Fc epsilon RI-mediated degranulation. Nat Med 2002;8: 518-21.

101. Zhang K, Zhu D, Kepley C, Terada T, Saxon A. Chimeric human Fc gamma-allergen fusion proteins in the prevention of allergy. Immunol Allergy Clin North Am 2007;27:93-103. 